\title{
Climatic effects on milk production traits and somatic cell score in lactating Holstein-Friesian cows in different housing systems
}

\author{
C. Lambertz, ${ }^{1}$ C. Sanker, and M. Gauly \\ Department of Animal Sciences, Georg-August University, Albrecht-Thaer-Weg 3, 37075 Göttingen, Germany
}

\begin{abstract}
The objective of this study was to compare the effect of the temperature-humidity index (THI) on milk production traits and somatic cell score (SCS) of dairy cows raised in 4 different housing systems: (1) warm loose housing with access to grazing (WG), (2) warm loose housing without access to grazing (WI), (3) cold loose housing with access to grazing (CG), and (4) cold loose housing without access to grazing (CI). For each of the 4 housing systems, 5 farms with a herd size of 70 to 200 lactating cows in Lower Saxony, Germany, were studied. Ambient temperature and relative humidity were recorded hourly in each barn to calculate THI. Milk production data included 21,546 test-day records for milk, fat, and protein yield, and SCS. These data were associated with the average THI of the $3 \mathrm{~d}$ preceding the respective measurement, which was divided into 6 classes $(<45, \geq 45$ to $<50, \geq 50$ to $<55, \geq 55$ to $<60$, $\geq 60$ to $<65$, and $\geq 65$ ). Furthermore, bulk milk samples including the fat and protein percentage, and SCS taken 4 to 6 times per month were associated with the average and maximum THI of the $3 \mathrm{~d}$ before sampling. Data were recorded from April 2010 to March 2011. In each of the housing systems, monthly THI values above 60 , indicating heat stress, were recorded between June and September, with higher values in WI and WG. In all systems, fat-corrected milk, fat, and protein yields of the test-day records decreased in tendency from 60 $\leq \mathrm{THI}<65$ to THI $>65$. In WI and CI, values for SCS were greater in the class THI $>65$ than in $60 \leq$ THI $<65$, whereas no difference between any of the THI classes was found in WG and CG. The fat and protein percentage of the bulk milk samples decreased with increasing 3-d maximum THI in all 4 systems, whereas the SCS increased with increasing 3-d average THI. In conclusion, negative effects of heat stress conditions under a temperate climate on milk production traits and SCS were found, although a housing system being
\end{abstract}

Received July 2, 2013.

Accepted October 4, 2013.

${ }^{1}$ Corresponding author: clamber2@gwdg.de superior to the other systems in altering heat stress effects was not identified.

Key words: heat stress, milk production trait, somatic cell score, housing system

\section{INTRODUCTION}

Livestock production and welfare is affected by various factors due to complex interactions between the individual animal and the environment with its different factors. Especially when the scenarios of global warming are considered, heat stress of high-yielding dairy cows is an increasing concern of milk producers in Europe (Gauly et al., 2013). Compared with the reference period of 1971 to 2000, mean annual temperatures are predicted to rise by $1^{\circ} \mathrm{C}$ for the period of 2021 to 2050 and $2.5^{\circ} \mathrm{C}$ for the period of 2071 to 2100 in Lower Saxony, with the highest increases being expected during winter and the lowest increases during spring (Moseley et al., 2012). Warm periods are anticipated to increase by approximately $50 \%$ for the period of 2071 to 2100 . Besides rising environmental temperatures, increasing milk yields result in further increasing metabolic heat production of dairy cows. The zone of thermoneutrality shifts to lower temperatures as milk yield, feed intake, and metabolic heat production increases (Kadzere et al., 2002). As reported by Berman (2005), a shift in the daily milk yield from 35 to $45 \mathrm{~kg} / \mathrm{d}$ leads to a higher sensitivity to thermal stress and reduces the threshold temperature for intermediate heat stress by $5^{\circ} \mathrm{C}$. Under subtropical and tropical climatic conditions, several studies demonstrated the effects of environmental factors (temperature, relative humidity, solar radiation, and wind speed) on the productivity of beef and dairy cattle (West, 2003; Berman, 2005; Rhoads et al., 2009). These studies associated heat stress with decreases in productivity, such as decreasing DMI, milk yield, and reproductive performance. But studies on heat stress effects in temperate zones are rarely found. The temperature-humidity index (THI) is a commonly used indicator of thermal conditions and the degree of heat stress and incorporates the effects of ambient temperature as well as relative humidity (Yousef, 1987; Hubbard et al., 1999). According to Rhoads et al. (2009), 
the DMI and milk yield is lower in heat-stressed cows than in cows that are kept in a thermoneutral environment. In Germany, Brügemann et al. (2012) indicated a milk yield decline between 0.08 and $0.26 \mathrm{~kg}$ for each unit increase in THI unit, depending on the region. In addition to declines in feed intake and milk yield, significant decreases in milk components (protein and fat) and increases in SCS have been demonstrated in the hottest months of the year (Rodriquez et al., 1985; Bouraoui et al., 2002). Quist et al. (2008) reported seasonal differences between summer and winter in fat and protein yield for the first lactation. As already pointed out for the milk components, a seasonal pattern is also observed for SCS. Generally, SCS increases during the summer months (Norman et al., 2000; Bouraoui et al., 2002; Olde Riekerink et al., 2007).

Worldwide, dairy cows are kept in various production and housing systems (Schnier et al., 2003; Nardone et al., 2010). However, the extent to which these systems affect heat stress effects on dairy cows is unknown. According to Nardone et al. (2010), production systems can be divided into 3 main categories: (1) grazing or pastoral systems, (2) mixed agro-zootechnical or croplivestock systems, and (3) industrial or landless systems. In Central and Eastern Europe, mixed livestock systems dominate, whereas grazing systems are only found in distinct areas. In Lower Saxony, one-third of the cattle farms keep their cows in tied stables and two-thirds in loose-housing systems (German Federal Statistical Office, 2010). However, the number of loosehousing systems is increasing (Zähner et al., 2004). Schnier et al. (2004) classified loose-housing systems into warm and cold loose-housing systems according to the climatic conditions inside the barn. Whereas in cold loose-housing systems, the microclimatic conditions inside the barn are similar to the macroclimatic conditions outside (Schnier et al., 2003), warm loosehousing systems are characterized by relatively constant climatic conditions in the barn throughout the year (Schnier et al., 2004). Another important aspect in dairy husbandry is pasturing. About two-thirds of the 783,000 dairy cows in Lower Saxony were kept on pasture for an average of $24 \mathrm{wk} / \mathrm{yr}$ in 2009 (German Federal Statistical Office, 2010). Overall, the husbandry system has a substantial effect on the climatic conditions in dairy barns. In addition to other factors (e.g., nutrition, health status, parity, stage of lactation, and season of calving), the microclimatic conditions affect the performance of animals (Ziegler and Weniger, 1990; Gader et al., 2007).

Considering rising temperatures and the availability of different housing systems, the aim of this study was to evaluate heat stress effects on milk production traits and SCS in different housing systems in Lower Saxony, Germany.

\section{MATERIALS AND METHODS}

\section{Animals and Housing Systems}

The study was conducted on 20 dairy farms distributed over Lower Saxony, Germany. Herd sizes varied between 70 and 200 Holstein-Friesian cows raised in loose-housing systems with cubicles. Four different housing systems were differentiated: (1) warm loose housing with access to grazing (WG), (2) warm loose housing without access to grazing (WI), (3) cold loose housing with access to grazing (CG), and (4) cold loose housing without access to grazing (CI). In the 2 pasturing systems, WG and CG, cows had access to pasture from May to October. Cold and warm loose-housing systems differed by the construction of the roofs, with warm having insulated and cold loose-housing systems having non-insulated roofs. Five farms belonged to each of the 4 different housing systems.

\section{Milk Production Traits and SCS}

A total of 21,546 test-day records for milk yield, fat, and protein percentage, and SCC collected from April 2010 to March 2011 were included in the study. The data set comprised 5,070 test-day records from WI, 4,106 from WG, 6,824 from CI, and 5,546 from CG. Milk yield and fat percentage were used to calculate FCM (4\%) yield. Fat and protein yield were calculated from milk yield and fat and protein percentage, respectively. Somatic cell score was calculated as $\log _{2}$ $(\mathrm{SCC} / 100,000)+3$. Lactation was divided into 3 stages: early (0 to 100 DIM; 7,689 test-day records), mid (101 to 200 DIM; 7,276 test-day records), and late (201 to 305 DIM; 6,580 test-day records). Parity was divided into 3 classes: first lactation, second lactation, and $\geq 3$ lactations. Seasons of calving were defined as follows: spring (March to May), summer (June to August), autumn (September to November), and winter (December to February).

In addition to the test-day records, bulk milk samplings were collected during the study period on 4 of the 5 farms of each housing system. Each farm was sampled 4 to 6 times per month and bulk milk was analyzed for fat and protein percentage, and SCS.

\section{Environmental Data}

Ambient temperature and relative humidity within the barns were recorded at 15-min intervals by data 
loggers (Tinytag Plus II, TGP-4500; Gemini Data Loggers Ltd., Chichester, UK). In each farm, 4 data loggers were installed, with 2 placed in the lying and 2 in the feeding area at a height of $3 \mathrm{~m}$ above the ground. The THI for every barn was calculated using hourly averages of the 4 data loggers according to the following formula:

$$
\begin{aligned}
\mathrm{THI}=(1.8 \times \mathrm{T} & +32)-(0.55-0.0055 \times \mathrm{RH}) \\
& \times(1.8 \times \mathrm{T}-26),
\end{aligned}
$$

where $\mathrm{T}$ is the air temperature in degrees Celsius and $\mathrm{RH}$ is the relative humidity in percent (NRC, 1971). The average and maximum THI of the $3 \mathrm{~d}$ preceding the milk sampling were used for statistical analysis (Bohmanova et al., 2008; Brügemann et al., 2011). The 3-d average THI was divided into 6 classes: $<45, \geq 45$ to $<50, \geq 50$ to $<55, \geq 55$ to $<60, \geq 60$ to $<65$, and $\geq 65$. The limits for the 6 different classes were defined based on the number of observations found in each of these classes.

\section{Statistical Analysis}

The data analysis was performed with the statistical package SAS 9.2 (SAS Institute, 2008). For the analysis of the THI, the following linear model was used:

$$
\mathrm{Y}_{\mathrm{ijkl}}=\mu+\mathrm{C}_{\mathrm{i}}+\mathrm{C}_{\mathrm{i}}\left(\mathrm{F}_{\mathrm{j}}\right)+\mathrm{M}_{\mathrm{k}}+\mathrm{e}_{\mathrm{ijkl}},
$$

where $\mathrm{Y}_{\mathrm{ijkl}}=$ observed THI value, $\mu=$ overall mean, $\mathrm{C}_{\mathrm{i}}$ = fixed effect of the housing system $(\mathrm{i}=\mathrm{WG}, \mathrm{WI}$, $\mathrm{CG}$, or $\mathrm{CI}), \mathrm{C}_{\mathrm{i}}\left(\mathrm{F}_{\mathrm{j}}\right)=$ fixed effect of the farm within the housing system ( $\mathrm{j}=1$ to 20$), \mathrm{M}_{\mathrm{k}}=$ fixed effect of month $\left(\mathrm{k}=\right.$ April to March), and $\mathrm{e}_{\mathrm{ijk}}=$ random error. The significance of the fixed effects was analyzed by using the Tukey test with a significance level of $P<0.05$.

Parameters of the test-day records were analyzed using PROC MIXED of SAS with the following model:

$$
\begin{aligned}
\mathrm{Y}_{\mathrm{ijklmno}} & =\mu+\mathrm{SL}_{\mathrm{i}}+\mathrm{PA}_{\mathrm{j}}+\mathrm{SC}_{\mathrm{k}}+\mathrm{C}_{\mathrm{l}}+\mathrm{C}_{\mathrm{l}}\left(\mathrm{F}_{\mathrm{m}}\right) \\
& +\mathrm{cTHI}_{\mathrm{n}}+\mathrm{F}_{\mathrm{m}}\left(\mathrm{cow}_{\mathrm{o}}\right)+\mathrm{e}_{\mathrm{ijklmno}},
\end{aligned}
$$

where $Y_{\mathrm{ijk} k m n o}=$ observed value for FCM, fat, and protein yield, or SCS; $\mu=$ mean effect; $\mathrm{SL}_{\mathrm{i}}=$ fixed effect of the stage of lactation ( $\mathrm{i}=$ early, mid, or late); $\mathrm{PA}_{\mathrm{j}}$ $=$ fixed effect of the parity $(\mathrm{j}=$ first, second, or $\geq 3$ lactation); $\mathrm{SC}_{\mathrm{k}}=$ fixed effect of season of calving ( $\mathrm{k}=$ spring, summer, autumn, or winter); $\mathrm{C}_{1}=$ fixed effect of the housing system $(\mathrm{l}=\mathrm{WG}, \mathrm{WI}, \mathrm{CG}$, or $\mathrm{CI}) ; \mathrm{C}_{1}\left(\mathrm{~F}_{\mathrm{m}}\right)$ $=$ fixed effect of the farm within the housing system $(\mathrm{m}=1$ to 20$) ;$ cTHI $_{\mathrm{n}}=$ fixed effect of the THI classes (n $<45 ; \geq 45$ to $<50 ; \geq 50$ to $<55 ; \geq 55$ to $<60 ; \geq 60$ to $<65$; or $\geq 65) ; \mathrm{F}_{\mathrm{m}}\left(\mathrm{cow}_{\mathrm{o}}\right)=$ repeated effect of the cow within farm; and $\mathrm{e}_{\mathrm{ijklmno}}=$ random error.

Interaction effects between THI classes and systems on FCM, fat, and protein yield, or SCS, respectively, were determined using PROC MIXED, where the fixed effect of the interactions between the housing systems and the THI classes was added to the model described above. For all models, the significance of the fixed effects was analyzed by using the Tukey test with a significance level of $P<0.05$.

The association of THI values (3-d average and $3-\mathrm{d}$ maximum THI) with milk production traits and SCS were analyzed with Pearson correlation. Due to higher correlations of the $3-\mathrm{d}$ average THI, this parameter was used for the multivariable mixed model to test the regression effect. Season of calving and farm as fixed factors and cow within farm as random factor were included.

To determine the association between the THI values with the bulk milk components, a multivariable mixed model was fitted to the data, including the housing system, the farm within the housing system, and the month as fixed effects. As described for the test-day records, Pearson correlations were calculated for the different bulk milk components. The greatest correlations of fat and protein percentage to the average THI and of SCS to the maximum THI of the $3 \mathrm{~d}$ preceding the measurements were calculated and, therefore, these parameters were used for the linear regression model of the bulk milk data using PROC MIXED. Season was included as a fixed factor and farm as a random factor.

\section{RESULTS}

\section{Environmental Conditions}

The average monthly THI values in the warm loosehousing systems were higher compared with the cold loose-housing systems, with the greatest differences between warm and cold loose-housing systems being observed during the winter months (Figure 1). Monthly THI averages exceeded the threshold for heat stress of THI $=60$ proposed by Brügemann et al. (2010, 2012) from June to September. During this period, no difference between the systems of the barn THI was noted. Maximum THI values exceeded 72 from April to September in systems without pasturing and from April to October in pasture-based systems. Throughout the experimental period, the highest mean as well as maximum THI values were recorded in July. Compared with WG, WI had slightly lower THI values. Hourly 


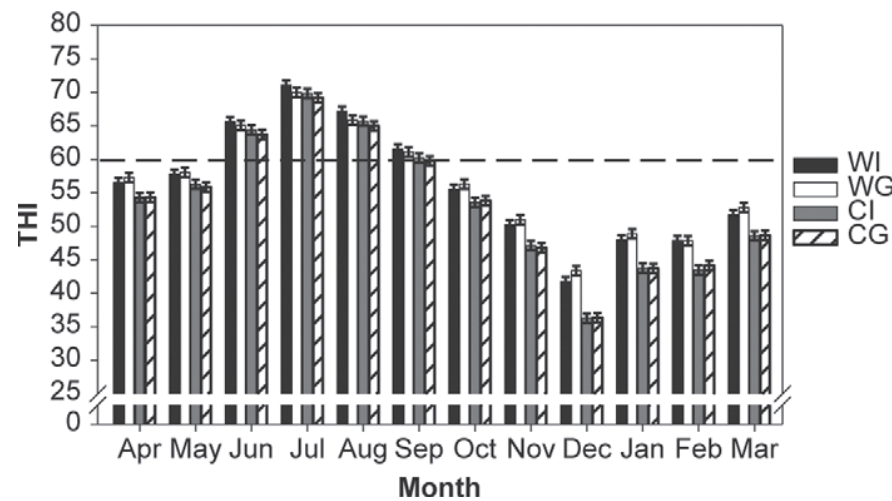

Figure 1. Temperature-humidity index (THI) in the warm loosehousing system without grazing (WI; black column), warm loose-housing system with grazing (WG; white column), cold loose-housing system without grazing (CI; gray column), and cold loose-housing system with grazing (CG; cross-hatched column) from April 2010 to March $2011(\mathrm{LSM} \pm \mathrm{SE} ; \mathrm{n}=5)$. The horizontal dashed line represents the heat stress threshold defined by Brügemann et al. $(2010,2012)$.

THI values above 60 were recorded on at least $169 \mathrm{~d}$ in all systems. From June to September this threshold was exceeded almost every day.

\section{Test-Day Records}

Across all systems, FCM, fat, and protein yield, and SCS averaged $( \pm \mathrm{SD}) 32.1 \pm 8.3,1.28 \pm 0.34,1.09 \pm$ 0.26 , and $2.92 \pm 1.67 \mathrm{~kg}$ over the whole study period. In Table 1, the different parameters of the test-day records classified by the THI values recorded during the last $3 \mathrm{~d}$ preceding the measurement are given. Compared with the lowest THI class $(<45)$, greater FCM yields were recorded for WI when THI ranged between 60 and 65 or $\geq 65(P<0.05)$. In contrast, FCM was lower in the THI class $\geq 65$ than in $55 \leq$ THI $<60$ and 50 $\leq$ THI $<55$ in CI and CG, respectively $(P<0.05)$. For all systems, FCM decreased in tendency from 60 $\leq$ THI $<65$ to THI $\geq 65$. The 2 grazing systems had lower FCM compared with the 2 other systems. Accordingly, the fat yield was lower $(P<0.05)$ for WI at $60 \leq \mathrm{THI}<65$ compared with THI $\geq 65$ but was not different among housing systems. Similarly, the protein yield tended to be lower in THI $\geq 65$ compared with 60 $\leq \mathrm{THI}<65$. For SCS, contrasting results between the 4 systems were observed. Greater values were recorded in the class THI $<65$ than in $60 \leq \mathrm{THI} \geq 65$ in WI and CI $(P<0.05)$, whereas no difference between any of the THI classes was found in the 2 other systems.

Based on findings of Brügemann et al. (2010, 2012), which indicated a THI of 60 as an upper critical THI for lactating cows associated with decreasing milk and protein yields in different production systems under similar climatic conditions in Germany, a linear regres- sion analysis between 3-d average THI and the tested parameters in the 4 housing systems was conducted. In this analysis only test-day records, recorded when the 3 -d average THI values were above 60 , were included. Results of the regression analysis at 3 different stages of lactation are presented in Table 2. Considering the lactation status, the highest declines in milk production traits associated with THI values above 60 were indicated in the late lactation (201 to 305 DIM). Regression coefficients were lower in WG and CI than in WI and CG. Similarly to FCM, the fat yield was negatively associated with the THI. Again, the highest rates were calculated in late-lactating dairy cows with higher rates observed for WI and CG compared with the other 2 systems. With increasing THI, the protein yields decreased more markedly in WG and CG than in WI and CI. In contrast, the increases in SCS with THI were more pronounced for WI and CI than for the 2 pasturing systems for all lactation statuses.

\section{Bulk Milk Samplings}

The fat percentage of the bulk milk samples was negatively influenced by increasing 3 -d maximum THI values in all 4 systems $(P<0.001$; Figure 2$)$ and the decrease was more pronounced in WG and WI compared with CG and CI. In accordance, the protein percentage decreased with increasing 3 -d maximum THI $(P$ $<0.001$; Figure 3). As observed for the fat percentage, the greatest decreases were calculated in WG and WI.

For bulk milk SCS, a higher correlation to the 3-d average THI than to the 3 -d maximum THI was calculated and, thus, the former parameter was used for the regression analysis. Figure 4 illustrates the positive relationships of the 3 -d average THI on the SCS differentiated by the systems. In all systems, the SCS increased with increasing 3 -d average THI $(P<0.01$ in WI and CG; $P<0.1$ in WG and CI), whereas the greatest variation was found in WI.

\section{DISCUSSION}

Environmental factors such as temperature, relative humidity, solar radiation, and air movement and their interactions often limit the performance of dairy cows (West, 2003). Different housing systems might influence the effect of these environmental conditions on milk production. Incorporating the ambient temperature and relative humidity, the THI is a widely used indicator of thermal conditions and the degree of heat stress. Although several thresholds for heat stress are defined in the literature, they vary in accordance with the THI formula used and were assessed under different climatic conditions (Johnson, 1987; Bohmanova et al., 2007); 
Table 1. Fat-corrected milk (4\%), fat, and protein yields, and SCS for temperature-humidity index (THI) classes averaged for the last $3 \mathrm{~d}$ preceding the measurement in 4 different housing systems $(\mathrm{n}=5)$ from April 2010 to March 2011 (LSM \pm SEM)

\begin{tabular}{|c|c|c|c|c|c|}
\hline \multirow{2}{*}{$\begin{array}{l}\text { Trait and } \\
\text { THI class }\end{array}$} & \multicolumn{4}{|c|}{ Housing system ${ }^{1}$} & \multirow[b]{2}{*}{ SEM } \\
\hline & WI & WG & $\mathrm{CI}$ & $\mathrm{CG}$ & \\
\hline \multicolumn{6}{|c|}{ FCM (kg/d) } \\
\hline$\leq 45$ & $31.4^{\mathrm{a}}$ & $29.5^{\mathrm{a}}$ & $32.3^{\mathrm{ab}}$ & $32.1^{\mathrm{ab}}$ & 0.4 \\
\hline$\overline{45}-50$ & $32.2^{\mathrm{ab}}$ & $29.4^{\mathrm{a}}$ & $32.3^{\mathrm{ab}}$ & $31.8^{\mathrm{ab}}$ & 0.3 \\
\hline $50-55$ & $32.5^{\mathrm{ab}}$ & $30.2^{\mathrm{a}}$ & $32.5^{\mathrm{ab}}$ & $32.7^{\mathrm{b}}$ & 0.2 \\
\hline $55-60$ & $32.0^{\mathrm{ab}}$ & $29.8^{\mathrm{a}}$ & $32.9^{\mathrm{a}}$ & $32.0^{\mathrm{ab}}$ & 0.2 \\
\hline $60-65$ & $33.7^{\mathrm{c}}$ & $30.8^{\mathrm{a}}$ & $32.4^{\mathrm{ab}}$ & $31.4^{\mathrm{ac}}$ & 0.3 \\
\hline$\geq 65$ & $32.8^{\mathrm{bc}}$ & $29.9^{\mathrm{a}}$ & $31.6^{\mathrm{b}}$ & $30.5^{\mathrm{c}}$ & 0.3 \\
\hline \multicolumn{6}{|c|}{ Fat yield $(\mathrm{kg} / \mathrm{d})$} \\
\hline$\leq 45$ & $1.27^{\mathrm{a}}$ & $1.19^{\mathrm{a}}$ & $1.29^{\mathrm{a}}$ & $1.29^{\mathrm{ab}}$ & 0.01 \\
\hline$\overline{45}-50$ & $1.30^{\mathrm{ab}}$ & $1.19^{\mathrm{a}}$ & $1.28^{\mathrm{a}}$ & $1.29^{\mathrm{ab}}$ & 0.01 \\
\hline $50-55$ & $1.30^{\mathrm{a}}$ & $1.22^{\mathrm{a}}$ & $1.28^{\mathrm{a}}$ & $1.31^{\mathrm{a}}$ & 0.01 \\
\hline $55-60$ & $1.28^{\mathrm{a}}$ & $1.18^{\mathrm{a}}$ & $1.30^{\mathrm{a}}$ & $1.27^{\mathrm{bd}}$ & 0.01 \\
\hline $60-65$ & $1.35^{\mathrm{b}}$ & $1.23^{\mathrm{a}}$ & $1.26^{\mathrm{ab}}$ & $1.24^{\mathrm{cd}}$ & 0.01 \\
\hline$\geq 65$ & $1.30^{\mathrm{a}}$ & $1.18^{\mathrm{a}}$ & $1.23^{\mathrm{b}}$ & $1.20^{\mathrm{c}}$ & 0.01 \\
\hline \multicolumn{6}{|c|}{ Protein yield $(\mathrm{kg} / \mathrm{d})$} \\
\hline$\leq 45$ & $1.07^{\mathrm{ab}}$ & $1.01^{\mathrm{ab}}$ & $1.12^{\mathrm{a}}$ & $1.10^{\mathrm{a}}$ & 0.01 \\
\hline$\overline{45}-50$ & $1.08^{\mathrm{ab}}$ & $1.03^{\mathrm{ab}}$ & $1.11^{\mathrm{a}}$ & $1.08^{\mathrm{a}}$ & 0.01 \\
\hline $50-55$ & $1.10^{\mathrm{ab}}$ & $1.03^{\mathrm{ab}}$ & $1.11^{\mathrm{a}}$ & $1.10^{\mathrm{a}}$ & 0.01 \\
\hline $55-60$ & $1.07^{\mathrm{a}}$ & $1.02^{\mathrm{ab}}$ & $1.13^{\mathrm{a}}$ & $1.10^{\mathrm{a}}$ & 0.01 \\
\hline $60-65$ & $1.10^{\mathrm{ab}}$ & $1.05^{\mathrm{a}}$ & $1.13^{\mathrm{a}}$ & $1.07^{\mathrm{ab}}$ & 0.01 \\
\hline$\geq 65$ & $1.10^{\mathrm{ab}}$ & $1.01^{\mathrm{b}}$ & $1.09^{\mathrm{a}}$ & $1.03^{\mathrm{b}}$ & 0.01 \\
\hline \multicolumn{6}{|l|}{$\mathrm{SCS}$} \\
\hline$\leq 45$ & $2.70^{\mathrm{ab}}$ & $3.25^{\mathrm{a}}$ & $2.95^{\mathrm{ab}}$ & $2.82^{\mathrm{a}}$ & 0.09 \\
\hline$\overline{45}-50$ & $2.73^{\mathrm{ab}}$ & $2.91^{\mathrm{a}}$ & $2.94^{\mathrm{ab}}$ & $2.89^{\mathrm{a}}$ & 0.08 \\
\hline $50-55$ & $2.59^{\mathrm{b}}$ & $3.15^{\mathrm{a}}$ & $2.84^{\mathrm{ab}}$ & $2.88^{\mathrm{a}}$ & 0.05 \\
\hline $55-60$ & $2.67^{\mathrm{ab}}$ & $3.11^{\mathrm{a}}$ & $2.99^{\mathrm{ab}}$ & $2.94^{\mathrm{a}}$ & 0.06 \\
\hline $60-65$ & $2.63^{\mathrm{ab}}$ & $3.04^{\mathrm{a}}$ & $2.71^{\mathrm{a}}$ & $2.91^{\mathrm{a}}$ & 0.06 \\
\hline$\geq 65$ & $2.92^{\mathrm{a}}$ & $2.99^{\mathrm{a}}$ & $3.03^{\mathrm{b}}$ & $2.94^{\mathrm{a}}$ & 0.08 \\
\hline
\end{tabular}

${ }^{\mathrm{a}-\mathrm{d}}$ Values within the same column and trait with different superscript letters are significantly different $(P<$ $0.05)$.

${ }^{1} \mathrm{WI}=$ warm loose housing without grazing; $\mathrm{WG}=$ warm loose housing with grazing; $\mathrm{CI}=$ cold loose housing without grazing; $\mathrm{CG}=$ cold loose housing with grazing.

the threshold defined by Brügemann et al. (2010, 2012) as the upper critical THI for lactating cows associated with decreasing milk and protein yields in different production systems in Lower Saxony, Germany, was used in the present study. This seems to be an appropriate threshold for heat stress under the prevailing environmental conditions of this region. Under consideration of this threshold, dairy cows were found to be exposed to heat stress not only during summer months, but also on most of the days in spring and autumn.

Differentiated by the housing system, annual THI values were higher in the 2 warm (WG and WI) than in the 2 cold loose-housing systems (CG and CI). As indicated by Schnier et al. (2003), warm loose-housing systems are characterized by relatively constant climatic conditions due to their construction (e.g., isolation, airflow, and natural ventilation). Compared with cold loose-housing systems, the insulation prevents rapid heating and, at the same time, the cooling of the barn takes longer. The findings of this study are well in agreement with those of Schnier et al. (2003), as the cold housing systems were characterized by lower THI values, particularly during the winter months. In systems with pasturing, where the animals are not in the barn during the daytime and, thus, do not release heat in the barn, lower heat loads might be expected, especially during summer months. However, these differences between systems with and without pasturing could not be confirmed in the present study. Under environmental conditions of heat stress, cows in the pasturing systems were able to choose whether to stay in the barn or to graze on pasture and, thus, might have dealt with the exposure to heat stress more efficiently than cows kept indoors constantly. In this context, shade is one of the most important management techniques to reduce heat stress (Brown-Brandl et al., 2005). Particularly in the warm loose-housing systems, pasturing is an important factor, because insulated barns cool down more slowly than open barns (Krohn et al., 1992).

With respect to heat stress effects on milk production, it was widely shown in previous research studies that the climatic conditions during the $3 \mathrm{~d}$ preceding 
Table 2. Linear regression coefficients between temperature-humidity index (THI; THI >60) and FCM (4\%), fat, and protein yields, and SCS at different stages of lactation (early: 0-100 DIM; mid: 101-200 DIM; late 201-305 DIM) in 4 different housing systems $(\mathrm{n}=5)$ from April 2010 to March 2011

\begin{tabular}{|c|c|c|c|c|c|}
\hline \multirow[b]{2}{*}{ Trait } & \multicolumn{4}{|c|}{ Housing system $^{1}$} & \multirow[b]{2}{*}{ SEM } \\
\hline & WI & WG & CI & CG & \\
\hline \multicolumn{6}{|c|}{$\mathrm{FCM}(\mathrm{kg} / \mathrm{d})$} \\
\hline Intercept & 36.6 & 36.9 & 38.0 & 43.5 & 4.8 \\
\hline Early & -0.042 & +0.000 & -0.004 & -0.093 & 0.08 \\
\hline Mid & -0.105 & $-0.072^{*}$ & -0.071 & $-0.149^{*}$ & 0.07 \\
\hline Late & $-0.179 *$ & $-0.123^{*}$ & -0.129 & $-0.197^{*}$ & 0.07 \\
\hline \multicolumn{6}{|c|}{ Fat yield $(\mathrm{kg} / \mathrm{d})$} \\
\hline Intercept & 1.69 & 1.40 & 1.49 & 1.78 & 0.2 \\
\hline Early & $-0.005^{*}$ & +0.000 & -0.000 & -0.005 & 0.003 \\
\hline Mid & $-0.008^{*}$ & $-0.003^{*}$ & -0.003 & $-0.007^{*}$ & 0.003 \\
\hline Late & $-0.010^{*}$ & $-0.005^{*}$ & -0.005 & $-0.009^{*}$ & 0.003 \\
\hline \multicolumn{6}{|c|}{ Protein yield $(\mathrm{kg} / \mathrm{d})$} \\
\hline Intercept & 1.04 & 1.59 & 1.18 & 1.50 & 0.2 \\
\hline Early & +0.000 & $-0.005^{*}$ & +0.001 & -0.004 & 0.002 \\
\hline Mid & -0.001 & $-0.006^{*}$ & -0.001 & -0.005 & 0.002 \\
\hline Late & -0.003 & $-0.008^{*}$ & -0.002 & $-0.006^{*}$ & 0.002 \\
\hline \multicolumn{6}{|l|}{ SCS } \\
\hline Intercept & 1.74 & 3.56 & -0.93 & 2.54 & 1.2 \\
\hline Early & $+0.027^{*}$ & -0.002 & $+0.051^{*}$ & +0.002 & 0.02 \\
\hline Mid & $+0.029^{*}$ & +0.003 & $+0.060^{*}$ & +0.006 & 0.02 \\
\hline Late & $+0.034^{*}$ & +0.007 & $+0.062^{*}$ & +0.017 & 0.02 \\
\hline
\end{tabular}

${ }^{1} \mathrm{WI}=$ warm loose housing without grazing; $\mathrm{WG}=$ warm loose housing with grazing; $\mathrm{CI}=$ cold loose housing without grazing; $\mathrm{CG}=$ cold loose housing with grazing.

${ }^{*} P<0.05$.

the measurement were more highly correlated with milk yield and composition than the average conditions of other periods preceding the sampling (West, 2003; Bouraoui et al., 2002). Although the FCM, fat, and protein yields tended to decrease from $60 \leq \mathrm{THI}<65$ to $\mathrm{THI} \geq 65$ in all systems, a significant difference between these 2 THI classes could not be confirmed. In other studies, the decrease in FCM, fat, and protein yields under heat stress conditions was more pronounced (Bouraoui et al., 2002; Quist et al., 2008). Under the Mediterranean climate, Bouraoui et al. (2002) reported a decrease in milk yield of $21 \%$ when the THI increased from 68 to 78 . For THI values above 69 , the milk yield decreased by $0.41 \mathrm{~kg} / \mathrm{d}$ per cow and THI unit increase. Bernabucci et al. (2010) studied the effect of heat stress over 2 yr under field conditions and calculated a decrease of $0.27 \mathrm{~kg}$ milk per day for each THI unit increase above 68 . Additionally, in a study conducted in the United States, the milk yield decreased by 0.23 to $0.59 \mathrm{~kg}$ per THI unit per day (Bohmanova et al., 2007). This decrease in milk yield of heat-stressed cows may be explained mainly by a lower DMI and a lower conversion efficiency of feed into milk ( $\mathrm{kg}$ of $\mathrm{FCM} / \mathrm{kg}$ of DMI) as reported by Bouraoui et al. (2002). A study in Scandinavia compared milk yield in cold and warm loose-housing systems (Schnier et al., 2003). In agreement with the current study, those authors recorded a lower milk yield in the cold loose-housing system.
Those authors concluded that for Ayrshire and Black and White dairy cows, the microclimatic conditions in combination with farm management allowed milk yield in cold loose housing to equal the yield in a warm loosehousing system.

The regression coefficients of THI on FCM found for the test-day records are comparable with those of Brügemann et al. (2012). For the same regions in Lower Saxony, but based on meteorological data of weather stations, those authors calculated milk yield declines per THI unit from $0.08 \mathrm{~kg}$ for regions with indoor systems (crop production regions) to $0.17 \mathrm{~kg}$ for grazingbased systems.

Another important factor influencing the effects of heat stress on milk production is the stage of lactation. However, results are controversial. Igono et al. (1992) and Novak et al. (2009) reported a greater decrease in early lactation than in mid or in late lactation. Thereby, Novak et al. (2009) mentioned that cows in early lactation are more sensitive to the effect of heat than cows in late lactation. Interestingly, in our study, the largest effects of heat stress on milk yield were observed in late lactation.

Indoor systems provide the possibility for a balanced and performance-adapted feeding ration. For grazingbased systems this is difficult due to the unpredictable feed intake on pasture. Nevertheless, a study on preferences for pasture versus freestall housing indicated that 


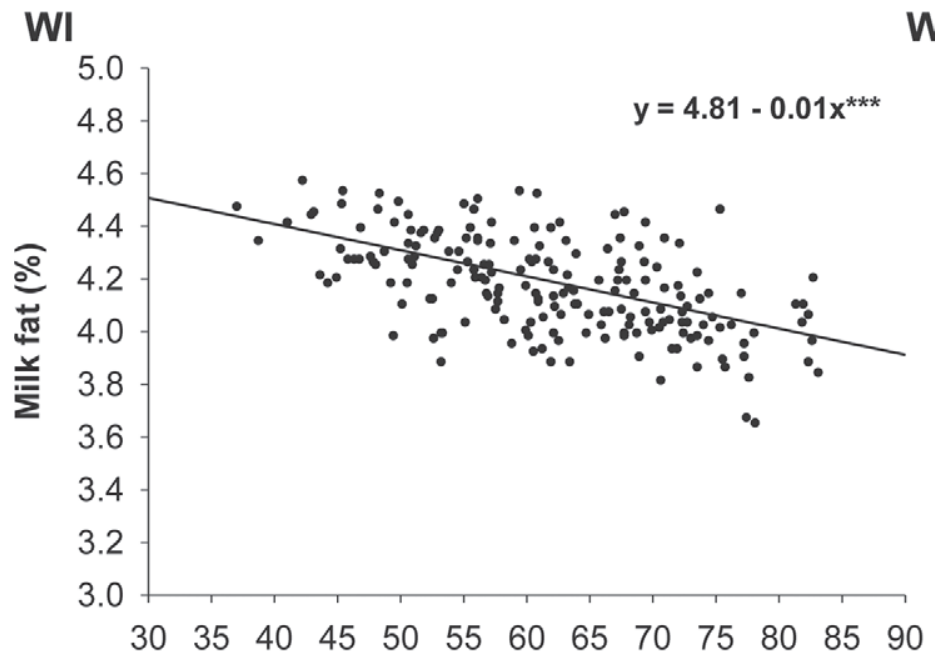

WG

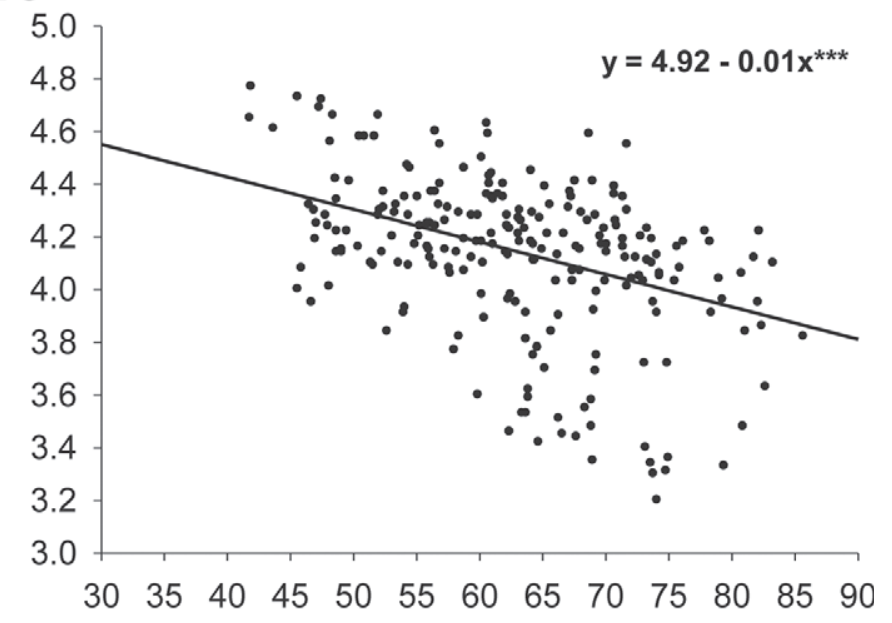

CG

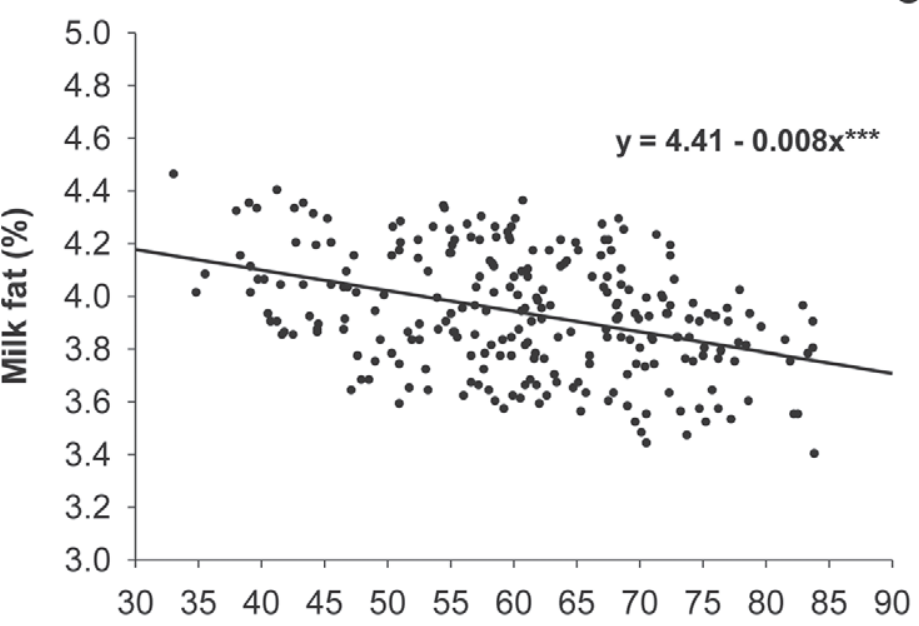

3-d maximum THI

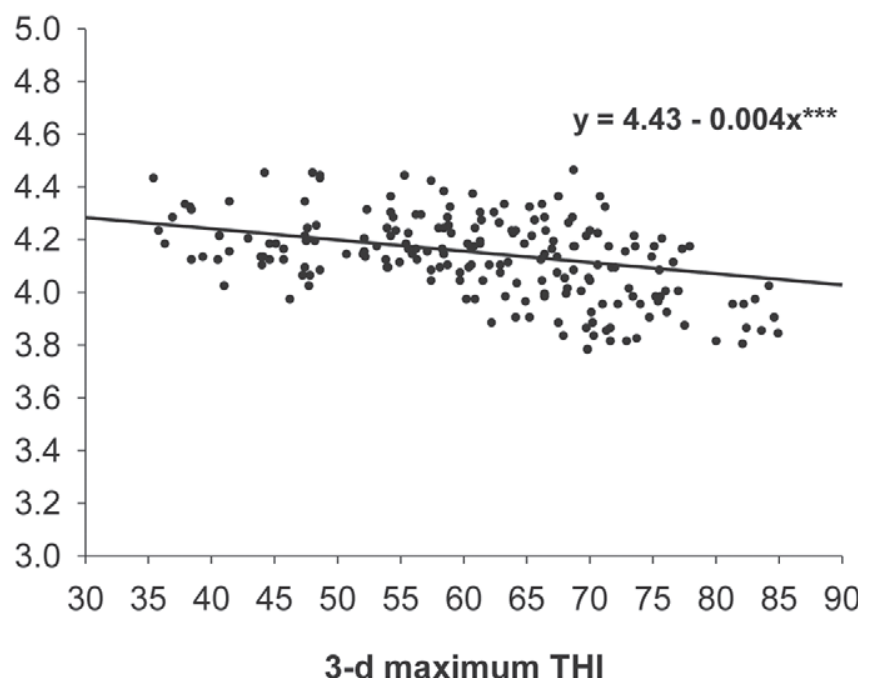

Figure 2. Relationship between maximum temperature-humidity index (THI) during the last $3 \mathrm{~d}$ preceding bulk milk sampling and fat percentage for the warm loose-housing system without access to grazing (WI; $\mathrm{n}=4, \mathrm{n}=192$ ), warm loose-housing system with access to grazing (WG; $\mathrm{n}=4, \mathrm{n}=228$ ), cold loose-housing system without access to grazing (CI; $\mathrm{n}=4, \mathrm{n}=254$ ), and cold loose-housing system with access to grazing $(C G ; n=4, n=195)$, where first $n=$ number of farms and second $\mathrm{n}=$ number of records within system. Mean $( \pm$ SD) fat percentage in the 4 systems was $\mathrm{WI}=4.2 \pm 0.2 \%, \mathrm{WG}=4.1 \pm 0.3 \%, \mathrm{CI}=3.9 \pm 0.2 \%$, and $\mathrm{CG}=4.1 \pm 0.2 \%$. *** Regression coefficients are significant at $P<0.001$.

cows with access to pasture spent $1 \mathrm{~h}$ per day less time feeding on TMR and, thereby, the DMI decreased by $2.9 \mathrm{~kg} / \mathrm{d}$ (Legrand et al., 2009). This may explain the higher FCM yields observed in WI and CI compared with the 2 grazing-based systems.

Not only the milk yield, but also its composition, is influenced by climatic conditions. The regression analysis of the test-day records indicated negative effects of THI values above 60 on the fat as well as protein yield in all systems, particularly in late lactation. Results of the bulk milk samplings confirmed the findings of the test-day records and a decrease in fat and protein percentage was associated with increasing thermal conditions in the barn. This, again, may be mainly due to decreases in DMI as a consequence of heat stress (Bouraoui et al., 2002; Collier et al., 2006) and, thereby, might have affected the milk fat content. Lower feed intake, selective consumption of concentrates, and minimal intake of forages predisposes cows to ruminal acidosis and lower milk fat content (Collier et al., 2006; Staples and Thatcher, 2011). Under Mediterranean climatic conditions, a decrease in milk fat percentage of $0.34 \%$ from spring to summer has been observed (Bouraoui et al., 2002). In agreement, other studies (Rodriquez et al., 1985) in heat-stress environments reported decreases in milk fat percentage 


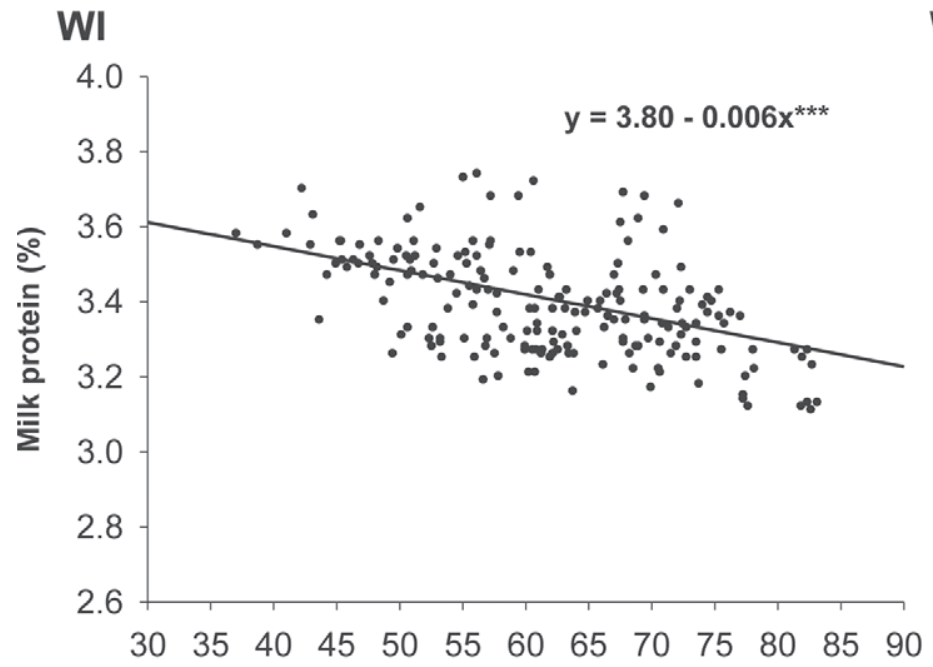

WG

\section{$\mathrm{Cl}$}

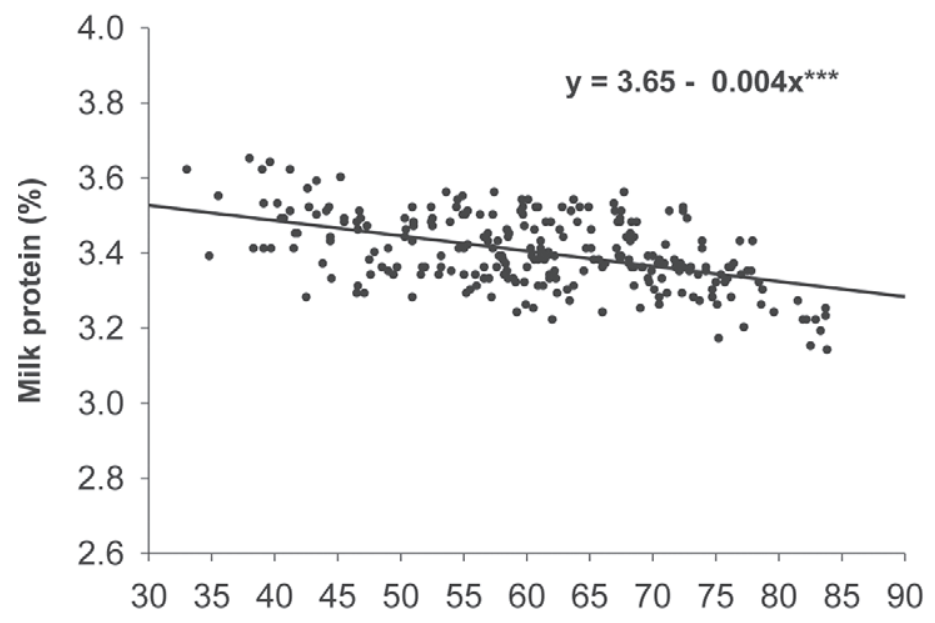

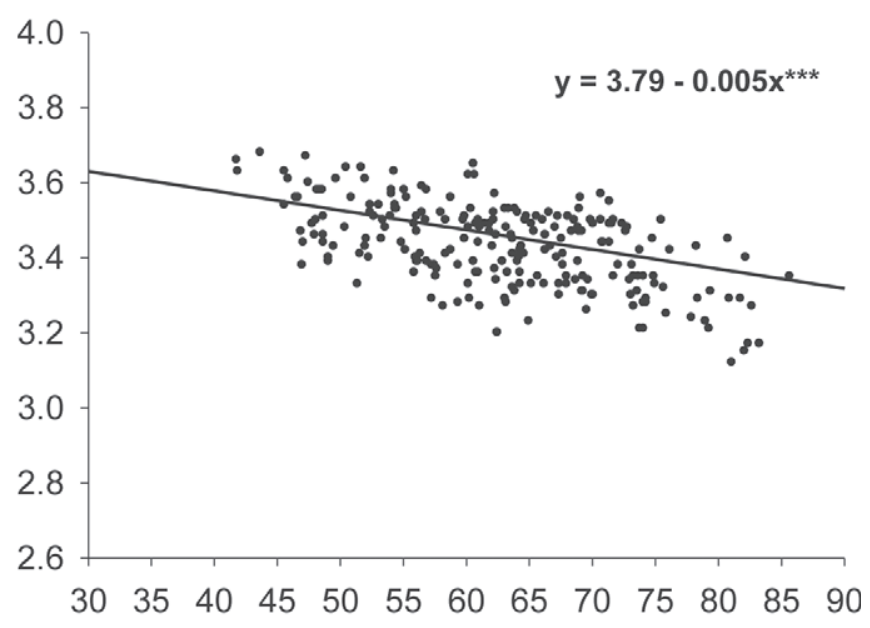

CG

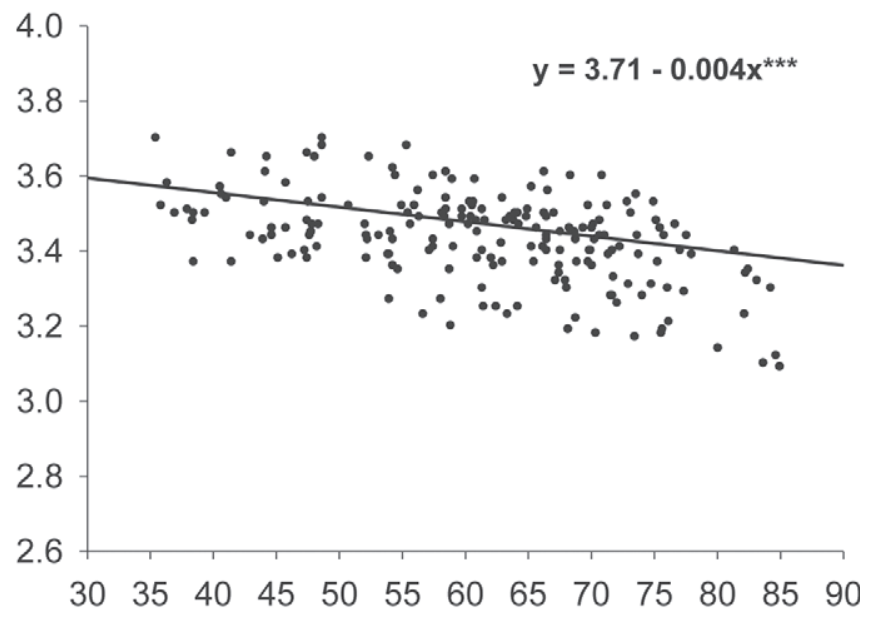

3-d maximum THI

Figure 3. Relationship between maximum temperature-humidity index (THI) during the last $3 \mathrm{~d}$ preceding bulk milk sampling and protein percentage for the warm loose-housing system without access to grazing (WI; $\mathrm{n}=4, \mathrm{n}=192$ ), warm loose-housing system with access to grazing (WG; $\mathrm{n}=4, \mathrm{n}=228$ ), cold loose-housing system without access to grazing (CI; $\mathrm{n}=4, \mathrm{n}=254$ ), and cold loose-housing system with access to grazing (CG; $\mathrm{n}=4, \mathrm{n}=195)$, where first $\mathrm{n}=$ number of farms and second $\mathrm{n}=$ number of records within system. Mean $( \pm \mathrm{SD})$ protein percentage in the 4 systems was $\mathrm{WI}=3.39 \pm 0.14 \%, \mathrm{WG}=3.44 \pm 0.11 \%, \mathrm{CI}=3.39 \pm 0.10 \%$, and $\mathrm{CG}=3.44 \pm 0.12 \%$. *** Regression coefficients are significant at $P<0.001$.

with increasing THI. Conversely, Knapp and Grummer (1991) found no significant depressions in fat percentages of heat-stressed cows. Quist et al. (2008) indicated a seasonal difference of $0.17 \mathrm{~kg} / \mathrm{d}$ in fat yield in the first lactation. As summarized by Gürtler and Schweigert (2000), the milk fat concentration and composition can vary in regard to the feed composition, breed, stage of lactation, parity, and season. Furthermore, milk components can be altered through the frequency of feeding. Previous studies indicated that fat is very sensitive to these changes (Sutton, 1989; Jenkins and McGuire, 2006).
The decreased milk protein percentage under heat stress conditions found for the test-day records and the bulk milk samples is in agreement with those reported by Bouraoui et al. (2002), Rhoads et al. (2009), and Shwartz et al. (2009). Rodriquez et al. (1985) and Knapp and Grummer (1991) suggested that with increasing maximum daily temperatures, the milk protein content decreases. Generally, heat-stress decreases in milk protein were related to lowered microbial protein synthesis in the rumen and lowered protein and feed intake (Staples and Thatcher, 2011). The cold loosehousing system in the current study exhibited higher 

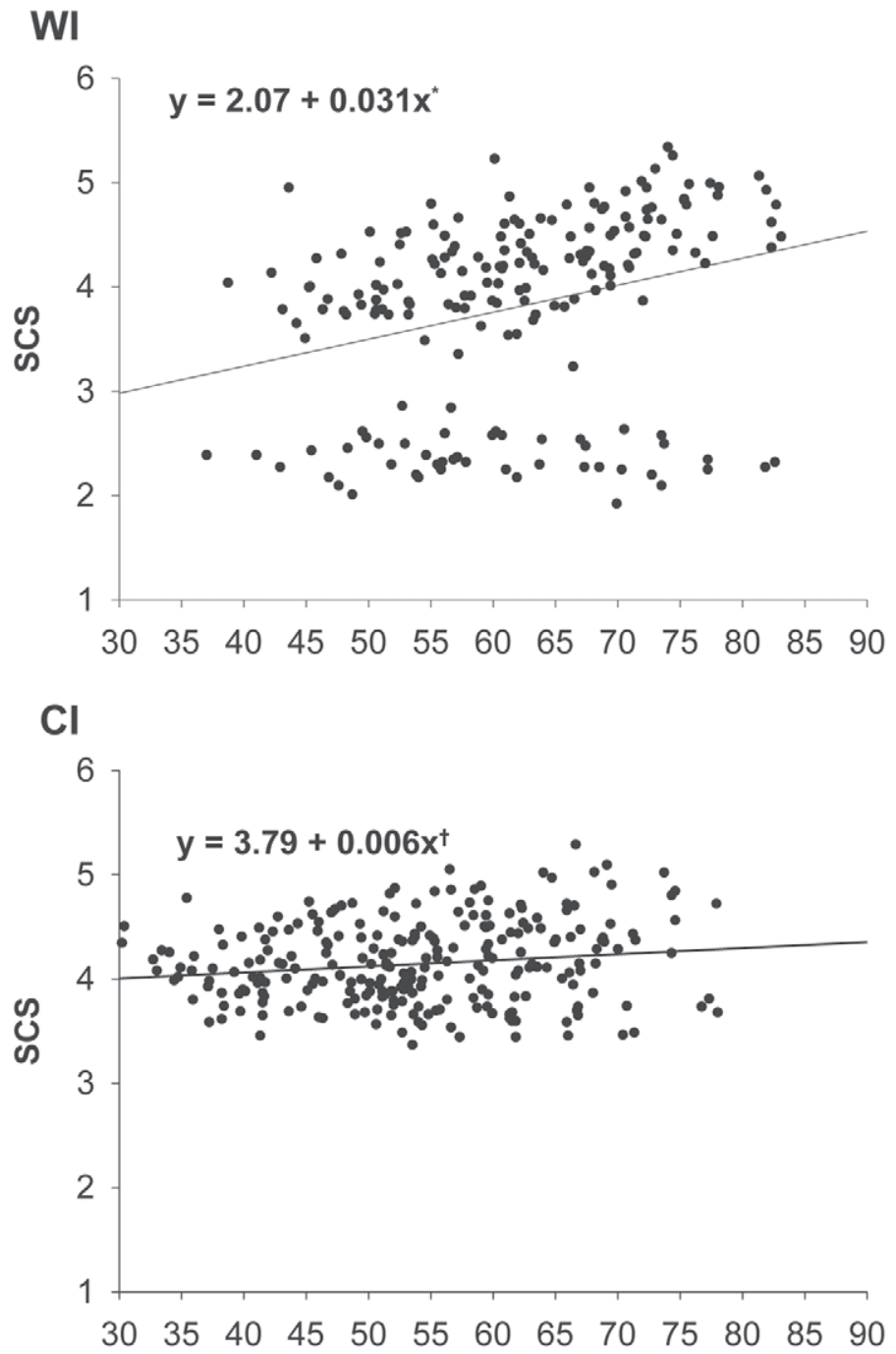

3-d maximum THI
WG

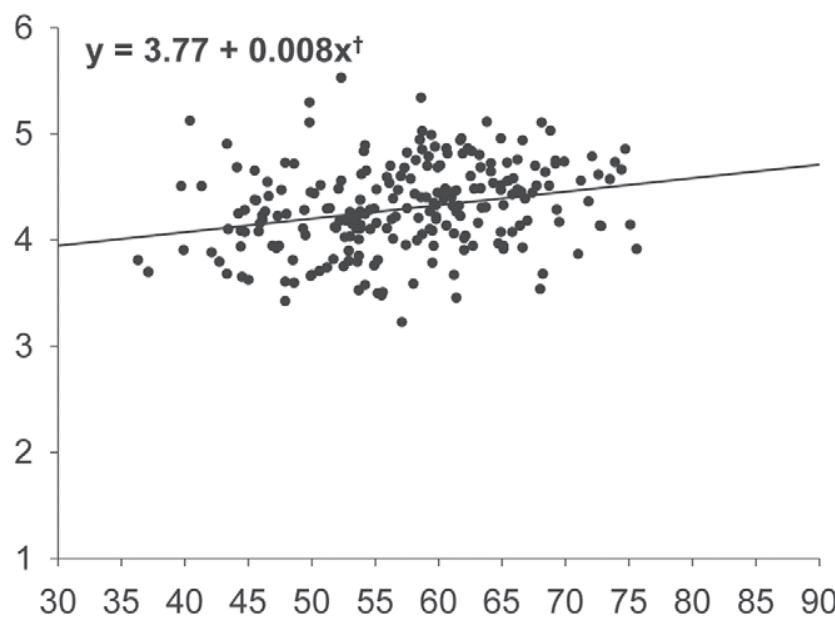

CG

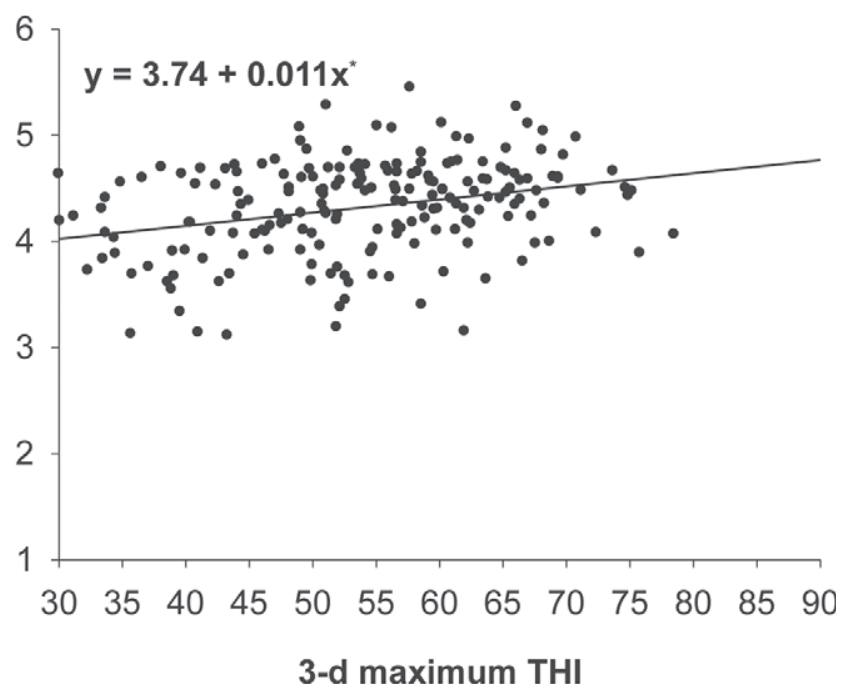

Figure 4. Relationship between maximum temperature-humidity index (THI) during the last $3 \mathrm{~d}$ preceding bulk milk sampling and SCS for the warm loose-housing system without access to grazing $(\mathrm{WI} ; \mathrm{n}=4, \mathrm{n}=192)$, warm loose-housing system with access to grazing (WG; $\mathrm{n}=4$, $\mathrm{n}=228$ ), cold loose-housing system without access to grazing (CI; $\mathrm{n}=4, \mathrm{n}=254$ ), and cold loose-housing system with access to grazing (CG; $\mathrm{n}=4, \mathrm{n}=195$ ), where first $\mathrm{n}=$ number of farms and second $\mathrm{n}=$ number of records within system. Mean ( \pm SD) SCS in the 4 systems was $\mathrm{WI}=3.81 \pm 0.91, \mathrm{WG}=4.30 \pm 0.41, \mathrm{CI}=4.14 \pm 0.39$, and $\mathrm{CG}=4.32 \pm 0.44 . \dagger^{*}$ Regression coefficients are significant at $P<0.1$ and 0.01.

maximum temperatures than the warm loose-housing system; however, a difference between the systems in the decrease in protein yield during periods of heat was not indicated. Primarily, the protein concentration is determined by the energy absorption or the energy content of the feed. A noneffective energy supply leads to a decrease in milk protein percentage (Gürtler and Schweigert, 2000). Rhoads et al. (2009) described a decrease in the milk protein content of $0.13 \%(2.73$ vs. $2.60 \%$ ) during heat stress compared with thermoneutral conditions. The increase in protein content in the milk after access to pasture is primarily due to an improvement in energy supply (Gürtler and Schweigert, 2000).

The milk SCS is the most important indicator for inflammation of the udder and is mainly influenced by the prevalence and incidence of subclinical and clinical mastitis (Dohoo and Meek, 1982). The results showed that in all housing systems, increasing THI values were associated with increasing SCS. Calculated on the basis of SCC and not on SCS, Bouraoui et al. (2002) indicated negative effects of heat stress with increasing SCC from spring to summer. In contrast, Simensen (1976) found a seasonal increase in SCC in cows kept on pasture, 
whereas no increase in SCC was recorded for cows in the indoor housing. Goldberg et al. (1992) found lower SCC in bulk milk of pasture-based dairy cows than of indoor-kept dairy cows.

Olde Riekerink et al. (2007) summarized that the prevalence and incidence of subclinical and clinical mastitis mainly influenced the bulk milk SCC in a herd. However, SCC is also dependent on other factors, such as parity, stage of lactation, management, type of housing, access to pasture, and environmental conditions such as temperature, humidity, and season. This is described in several other investigations (e.g., Bouraoui et al., 2002; Olde Riekerink et al., 2007). For example, Bouraoui et al. (2002) described in their study an increase of 450,000 somatic cells from spring to summer. Simensen (1976) related the seasonal pattern in SCC not only to environmental conditions, but also to effects of the different husbandry systems. That study indicated a seasonal increase in milk SCC of cows kept on pasture, but not in cows in the indoor group. In the present study, no clear difference existed between pasture and indoor systems. In all systems, an increase was found, with the highest increase being observed in WI. In contrast, Paape et al. (1973) described characteristics of heat stress, such as enhanced body temperature, decreased milk yield, and low circulating leucocytes and erythrocytes, but no increase in milk SCC during the period of high ambient temperature.

\section{CONCLUSIONS}

The environmental data of the present study indicated that dairy cows were exposed to heat stress conditions under temperate climate not only during summer months. This heat stress resulted in decreasing milk yield, fat, and protein percentages, and increasing SCS. Reflecting the low differences in the climatic conditions between the systems, heat stress effects did not vary between systems. Therefore, a housing system altering heat stress effects superior to the other systems was not identified.

\section{ACKNOWLEDGMENTS}

This study was funded by the Ministry for Science and Culture of Lower Saxony (Hanover, Germany) within the network KLIFF-Climate impact and adaptation research in Lower Saxony.

\section{REFERENCES}

Berman, A. 2005. Estimates of heat stress relief needs for Holstein dairy cows. J. Anim. Sci. 83:1377-1384.
Bernabucci, U., N. L. Lacetera, H. Baumgard, R. P. Rhoads, B. Ronchi, and A. Nardone. 2010. Metabolic and hormonal acclimation to heat stress in domesticated ruminants. Animal 4:1167-1183.

Bohmanova, J., I. Misztal, and J. B. Cole. 2007. Temperature-humidity indices as indicators of milk production losses due to heat stress. J. Dairy Sci. 90:1947-1956.

Bohmanova, J., I. Misztal, S. Tsuruta, H. D. Norman, and T. J. Lawlor. 2008. Short communication: Genotype by environment interaction due to heat stress. J. Dairy Sci. 91:840-846.

Bouraoui, R., M. Lahmar, A. Majdoub, M. Djemali, and R. Belyea. 2002. The relationship of temperature-humidity index with milk production of dairy cows in a Mediterranean climate. Anim. Res. 51:479-491.

Brown-Brandl, T. M., R. A. Eigenberg, J. A. Nienaber, and G. L. Hahn. 2005. Dynamic response indicators of heat stress in shaded and non-shaded feedlot cattle, part 1: Analyses of indicators. Biosystems Eng. 90:451-462.

Brügemann, K., E. Gernand, U. König von Borstel, and S. König. 2012. Defining and evaluating heat stress thresholds in different dairy cow production systems. Arch. Tierzucht 55:13-24.

Brügemann, K., E. Gernand, U. U. von Borstel, and S. König. 2011. Genetic analyses of protein yield in dairy cows applying random regression models with time and temperature $\times$ humidity dependent covariates. J. Dairy Sci. 94:4129-4139.

Brügemann, K., S. König, and E. Gernand. 2010. Assessment of heat stress in dairy cows by applying random regression test day models. Page 195 in Book of Abstr. 61st Ann. Mtg. Europ. Assoc. Anim. Prod., Heraklion, Greece. Wageningen Acad. Publ., Wageningen, the Netherlands.

Collier, R. J., G. E. Dahl, and M. J. VanBaale. 2006. Major advances associated with environmental effects on dairy cattle. J. Dairy Sci. 89:1244-1253.

Dohoo, I. R., and A. H. Meek. 1982. Somatic cell counts in bovine milk. Can. Vet. J. 23:119-125.

Gader, A. Z. A., M. K. A. Ahmed, L. M.-A. Musa, and K. J. Peters. 2007. Milk yield and reproductive performance of Friesian cows under Sudan tropical conditions. Arch. Tierzucht 50:155-164.

Gauly, M., H. Bollwein, G. Breves, K. Brügemann, S. Dänicke, G. Daş, J. Demeler, H. Hansen, J. Isselstein, S. König, M. Lohölter, M. Martinsohn, U. Meyer, M. Potthoff, C. Sanker, B. Schröder, N. Wrage, B. Meibaum, G. von Samson-Himmelstjerna, H. Stinshoff, and C. Wrenzycki. 2013. Future consequences and challenges for dairy cow production systems arising from climate change in Central Europe - A review. Animal 7:843-859.

German Federal Statistical Office. 2010. Land- und Forstwirtschaft, Fischerei - Wirtschaftsdünger, Stallhaltung, Weidehaltung - Landwirtschaftszählung/Agrarstrukturerhebung 2010. Accessed Jan. 1, 2012. https://www.destatis.de/DE/Publikationen/Thematisch/ LandForstwirtschaft/Produktionsmethoden/Stallhaltung_ Weidehaltung2032806109004.pdf.

Goldberg, J. J., E. E. Wildman, J. W. Pankey, J. R. Kunkel, D. B. Howard, and B. M. Murphy. 1992. The influence of intensively managed rotational grazing, traditional continuous grazing, and confinement housing on bulk milk quality and udder health. J. Dairy Sci. 75:96-104.

Gürtler, H., and F. J. Schweigert. 2000. Physiologie der Laktation. Pages 552-573 in Physiologie der Haustiere. 2nd ed. W. von Engelhardt and G. Breves, ed. Enke Verlag in MVS Medizinverlage, Stuttgart, Germany.

Hubbard, K. G., D. E. Stooksbury, G. L. Hahn, and T. L. Mader. 1999. A climatologic perspective on feedlot cattle performance and mortality related to the temperature-humidity index. J. Prod. Agric. 12:650-653.

Igono, M. O., G. Bjotvedt, and H. T. Sanford-Crane. 1992. Environmental profile and critical temperature effects on milk production of Holstein cows in desert climate. Int. J. Biometeorol. 36:77-87.

Jenkins, T. C., and M. A. McGuire. 2006. Major advances in nutrition: Impact on milk composition. J. Dairy Sci. 89:1302-1310.

Johnson, H. D. 1987. Bioclimate effects on growth, reproduction and milk production. Pages 35-57 in Bioclimatology and the Adaptation of Livestock. World Animal Science, Subseries B: Disciplinary 
Approach. Vol. 5. H. D. Johnson, ed. Elsevier Science Publishers B.V., Amsterdam, the Netherlands.

Kadzere, C. T., M. R. Murphy, N. Silanikove, and E. Maltz. 2002. Heat stress in lactating dairy cows: A review. Livest. Prod. Sci. 77:59-91.

Knapp, D. M., and R. Grummer. 1991. Response of lactating dairy cows to fat supplementation during heat stress. J. Dairy Sci. 74:2573-2579.

Krohn, C. C., L. Munksgaard, and B. Jonasen. 1992. Behaviour of dairy cows kept in extensive (loose housing/pasture) or intensive (tie stall) environments. I. Experimental procedure, facilities, time budgets - Diurnal and seasonal conditions. Appl. Anim. Behav. Sci. $34: 37-47$

Legrand, A. L., M. A. G. von Keyserlingk, and D. M. Weary. 2009. Preference and usage of pasture versus free-stall housing by lactating dairy cattle. J. Dairy Sci. 92:3651-3658.

Moseley, C., O. Panferov, C. Döring, J. Dietrich, U. Haberlandt, V. Ebermann, D. Rechid, F. Beese, and D. Jacob. 2012. Empfehlung für eine niedersächsische Strategie zur Anpassung an die Folgen des Klimawandels. Niedersächsisches Ministerium für Umwelt, Energie und Klimaschutz, Regierungskommission Klimaschutz, Hannover, Germany. Accessed Aug. 15, 2012. http://www.umwelt. niedersachsen.de/klimaschutz/aktuelles/107128.html\&af =1.

Nardone, A., B. Ronchi, N. Lacetera, M. S. Ranieri, and U. Bernabucci. 2010. Effects of climate changes on animal production and sustainability of livestock systems. Livest. Sci. 130:57-69.

Norman, H. D., R. H. Miller, J. R. Wright, and G. R. Wiggans. 2000. Herd and state means for somatic cell count from dairy herd improvement. J. Dairy Sci. 83:2782-2788.

Novak, P., J. Vokralova, and J. Broucek. 2009. Effects of the stage and number of lactation on milk yield of dairy cows kept in open barn during high temperatures in summer months. Arch. Tierzucht $52: 574-586$.

NRC. 1971. A Guide to Environmental Research on Animals. NRC, National Academy of Sciences, Washington, DC.

Olde Riekerink, R. G. M., H. W. Barkema, and H. Stryhn. 2007. The effect of season on somatic cell count and the incidence of clinical mastitis. J. Dairy Sci. 90:1704-1715.

Paape, M. J., W. D. Schultze, R. H. Miller, and J. W. Smith. 1973. Thermal stress and circulating erythrocytes, leucocytes, and milk somatic cells. J. Dairy Sci. 56:84-91.

Quist, M. A., S. J. LeBlanc, K. J. Hand, D. Lazenby, F. Miglior, and D. F. Kelton. 2008. Milking-to-milking variability for milk yield, fat and protein percentage, and somatic cell count. J. Dairy Sci. 91:3412-3423.
Rhoads, M. L., R. P. Rhoads, M. J. VanBaale, R. J. Collier, S. R. Sanders, W. J. Weber, B. A. Crooker, and L. H. Baumgard. 2009. Effects of heat stress and plane of nutrition on lactating Holstein cows: I. Production, metabolism, and aspects of circulating somatotropin. J. Dairy Sci. 92:1986-1997.

Rodriquez, L. A., G. Mekonnen, C. J. Wilcox, F. G. Martin, and W. A. Krienke. 1985. Effects of relative humidity, maximum and minimum temperature, pregnancy, and stage of lactation on milk composition and yield. J. Dairy Sci. 68:973-978.

SAS Institute. 2008. SAS/STAT ${ }^{\circledR}$ 9.2. User's Guide. SAS Institute Inc., Cary, NC

Schnier, C., S. Hielm, and H. S. Saloniemi. 2003. Comparison of milk production of dairy cows kept in cold and warm loose-housing systems. Prev. Vet. Med. 61:295-307.

Schnier, C., S. Hielm, and H. S. Saloniemi. 2004. Comparison of the breeding performance of cows in cold and warm loose-housing systems. Prev. Vet. Med. 62:135-151.

Shwartz, G., M. L. Rhoads, M. J. VanBaale, R. P. Rhoads, and L. H. Baumgard. 2009. Effects of a supplemental yeast culture on heatstressed lactating Holstein cows. J. Dairy Sci. 92:935-942.

Simensen, E. 1976. Milk somatic cells in dairy cows kept on pasture or confined indoors during the summer. Nord. Vet. Med. 28:603-609.

Staples, C. R., and W. W. Thatcher. 2011. Heat stress: Effects on milk production and composition. Pages 561-566 in Encyclopedia of Dairy Sciences. 2nd ed. J. W. Fuquay, P. F. Fox, and P. L. H. McSweeney, ed. Academic Press, Oxford, UK.

Sutton, J. D. 1989. Altering milk composition by feeding. J. Dairy Sci. $72: 2801-2814$.

West, J. W. 2003. Effects of heat-stress on production in dairy cattle. J. Dairy Sci. 86:2131-2144.

Yousef, M. K. 1987. Principles of bioclimatology and adaptation. Pages 17-31 in Bioclimatology and the Adaptation of Livestock. World Animal Science, Subseries B: Disciplinary Approach. Vol. 5. H. D. Johnson, ed. Elsevier Science Publishers B.V., Amsterdam, the Netherlands.

Zähner, M., L. Schrader, R. Hauser, M. Keck, W. Langhans, and B. Wechsler. 2004. The influence of climatic conditions on physiological and behavioural parameters in dairy cows kept in open stables. Anim. Sci. 78:139-147.

Ziegler, H., and J. H. Weniger. 1990. Leistungen, Thermoregulation und Energiehaushalt von Kühen der Rasse Deutsche Schwarzbunte unter Wärmebelastung. Züchtungskunde 62:254-264. 